\title{
Changes in Responses to the Inoculation of Fungi by Varying the Number of Subcultures of Rice Callus Culture.
}

\author{
Takeo Uchiyama*, Hiromi Kato*, Masako Ito* \\ and Nagahiro OgaSAWARA* \\ 内山武夫* · 加藤博美* ·伊藤正子* · 小笠原長宏* : 継代回数を異にする \\ イネカルスの植物病原系状菌接種に対する反応
}

\begin{abstract}
Authors recognized a decrease in morphogenetic potency of rice callus cultures by repeated subculturing. Based on this evidence, we investigated whether the rice callus cultures transferred from one to five times (F-callus) differed from that subcultured many times (M-callus) in its response to fungal infection. M-callus turned brown after 24 to 48 $\mathrm{hr}$ by inoculation of Pyricularia oryzae and other plant pathogenic fungi. These fungi colonized favorably on M-callus. But growth of inoculated fungi on $\mathrm{F}$-callus, with the exception of $P$. oryzae, was delayed in comparison with growth of fungi on $\mathrm{M}$-callus. This evidence was based on the fact that F-callus formed the antimicrobial substances by the affection of fungi. But this activity was not so strong. However, there were no differences in growth of $P$. oryzae on both rice callus cultures. Quantity of polyphenols sligthly increased, but free $o$-diphenols were scarcely detected in both infected and noninfected rice callus cultures. Phenylalanine ammonia-lyase activity was increased in $\mathrm{F}$-and $\mathrm{M}$-callus by inoculation of $P$. oryzae and other fungi. No increase in respiration was observed in F-callus inoculated with fungi. Although tenuazonic acid caused the formation of necrotic spot on rice leaves which resembled of naturally infected one, callus surface was not changed at $50 \mu \mathrm{g} / \mathrm{ml}$ of tenuazonic acid concentration, and callus growth was only inhibited with increasing concentration of it. We concluded from those results that $\mathrm{R}$-gene actions in rice plant were not exhibited in rice callus cultures.

(Received October 7, 1983)
\end{abstract}

Key Words : tissue cultures, rice callus, inoculation, Pyricularia oryzae.

\section{Introduction}

Nowadays, tissue culture techniques are employed for biotechnological application. ${ }^{18}$, ${ }^{21,24)}$. Responses of callus cultures inoculated with plant pathogenic fungi ${ }^{5,8,20)}$ and dual cultures of obligate parasites and their host ${ }^{5-7,28,29)}$ has also been studied.

In the previous paper ${ }^{17}$, we described that rice callus cultures transferred once a month for two years or more did not exbibit any resistance reaction to rice blast fungus. Invasion of inoculated fungi, whether pathogenic or non-pathogenic, was also easy. It is well known that properties of caullus cultures, such as morphogenetic potency ${ }^{22,34)}$,

* Faculty of Agriculture, Niigata University, Ikarashi, Niigata 新潟大学農学部 
production of secondary metabolite ${ }^{1,24)}$ and chromosom number ${ }^{33)}$ are gradually changed by repeated subculturing. From these data, we hypothesized that callus cultures subcultured fewer times (callus cultures transferred from one to five times, abbreviated to F-callus) would differ from that subcultured many times (for more than two years, abbreviated to $\mathrm{M}$-callus) in its response to fungal infection. In this paper we reported and discuss the responses of both callus cultures inoculated with plant pathogenic fungi.

\section{Materials and Methods}

Induction and maintenance of rice callus culture. The rice callus cultures (Oryza sativa L., Te-tep and No. 20) for these experiments were derived from seedlings germinated on a Murashige-Skoog (MS) medium containing 2, 4-dichlorophenoxyacetic acid $(2,4-\mathrm{D})^{17)}$. The rice callus cultures were maintained in dark at $30 \mathrm{C}$ and were successivly subcultured once a month.

Test microorganisms. Pyricularia oryzae $\mathrm{P}_{2}$ was used as rice blast fungus. Other non-pathogenic fungi to rice plants, such as Alternaria brassicicola, Botrytis cinerea and Fusarium oxysporum and the saprophytic fungi, Aspergillus oryzae, were also used for the purpose of comparison with the responses of inoculation of $P$. oryzae.

P. oryzae was grown on Misato agar at $28 \mathrm{C}$ for 10 days. A. brassicicola, B. cinerea and $F$. oxysporum, (provided by the Agricultural Chemicals Inspection Station), and $A$. oryzae, (a stock culture of our laboratory), were grown on potato sucrose (2\%) agar. A. brassicicola was incubated at $28 \mathrm{C}$ for 10 days, B. cinerea, F. oxysporum and A. oryzae, at $28 \mathrm{C}$ for 5 to 7 days. The rice callus cultures were inoculated with the conidia of these fungi with paint brushes from slant cultures and were incubated at $30 \mathrm{C}$ for 24 to $72 \mathrm{hr}$. The number of spores of $P$. oryzae, A. brassicicola and B. cinerea inoculated onto the callus cultures was about $10^{3}$ to $10^{4}$. For F. oxysporum and A. oryzae, the number was $10^{4}$ to $10^{5}$.

Preparation of microtome sections. Inoculated and non-inoculated rice callus cultures were fixed, and thin sections were examined under a microscope as described previously ${ }^{17)}$.

Pre paration of phenylalanine ammonia-lyase $(\boldsymbol{P A L})^{12,15)}$. For the preparation of crude enzyme, rice callus cultures were ground with a cold Potter-Elvehjem glass-teflon homogenizer in a $0.1 \mathrm{M}$ borate buffer solution $(\mathrm{pH} 8.8,1-2 \mathrm{ml} / \mathrm{g}$ callus cultures fresh weight) containing $10 \mu \mathrm{mol}$ glutathione (reduced form) and centrifuged at $12,000 \times \mathrm{g}$ for $20 \mathrm{~min}$ at $\mathrm{O}$ C. The supernatant was dialyzed against the same buffer (1/100 M) for about $20 \mathrm{hr}$ at $5 \mathrm{C}$. The dialyzed crude enzyme preparation was diluted with the same buffer to $3 \mathrm{ml}$ per gram fresh weight.

Assay method of phenylalanine ammonia lyase $(\boldsymbol{P A L})$. The enzymatic reactions were carried out in a system containing $100 \mu \mathrm{mol}$ of L-phenylalanine, $10 \mu \mathrm{mol}$ of glutathione (reduced form), $3 \mathrm{ml}$ of crude enzyme solution $5.4 \mathrm{ml}$ of $0.1 \mathrm{M}$ borate buffer $(\mathrm{pH} \mathrm{8.8)}$, the total volume being $10 \mathrm{ml}$. The enzyme reactions were conducted at $37 \mathrm{C}$ for $2 \mathrm{hr}$. The reaction mixtures were stopped with the addition of $6 \mathrm{~N} \mathrm{HCl}(0.5 \mathrm{ml})$ and heated in a boiling water bath for $3 \mathrm{~min}$. The reaction mixtures were centrifuged 
at $16,000 \times \mathrm{g}$ for $15 \mathrm{~min}$ at $0 \mathrm{C}$. The supernatants were poured into a separatory funnel and the formed trans-cinnamic acid was extracted with diethyl ether three times (30, 20 and $20 \mathrm{ml}$, respectively). Ethyl ether was dehydrated with anhydrous sodium sulfate, followed by evaporation in vacuo. The residue was dissolved in ethanol, diluted at 25 $\mathrm{ml}$ and the optical density of trans-cinnamic acid was measured at $273 \mathrm{~nm}$. Enzymatic activity was proportional to the amount of trans-cinnamic acid formed. It was further identified comparatively with authentic material by means of UV-absorption spectrum.

Assay method of tyrosine ammonia-lyase $(\boldsymbol{T A L})^{16)}$. Preparation of the crude enzyme solution was carried out using the same method as for PAL. Enzyme activity was estimated by measuring the amounts of $p$-coumaric acid formed. The enzyme reactions were carried out for $2 \mathrm{hr}$ at $40 \mathrm{C}$ in a system containing $5.5 \mu \mathrm{mol}$ of L-tyrosine, $3 \mathrm{ml}$ of crude enzyme solution and $3 \mathrm{ml}$ of $0.1 \mathrm{M}$ borate buffer ( $\mathrm{pH} 8.8$ ), the total volume being $10 \mathrm{ml}$. The enzyme reactions were stopped with the addition of $6 \mathrm{~N} \mathrm{HCl}$ $(0.3 \mathrm{ml})$ and heated in a boiling water bath for $3 \mathrm{~min}$ followed by centrifugation. $p$-cou maric acid was extracted from the supernatant with diethyl ether. The solvent phase was dehydrated with anhydrous sodium sulfate, followed by evaporation in vacuo. The residue was dissolved in ethanol and the optical density of $p$-coumaric acid was measured at $273 \mathrm{~nm}$. TAL activity was expressed in terms of $\mu$ mol $p$-coumaric acid formed.

Quantitative determination of total phenols. The Folin-Denis method ${ }^{23)}$ was used for the estimation of total phenols. An aliquot of the test solution containing not more than $0.5 \mathrm{ml}$ of methanol or ethanol, was well mixed with $0.5 \mathrm{ml}$ of Folin-Denis reagent. Exactly $3 \mathrm{~min}$ later, $1 \mathrm{ml}$ of saturated sodium carbonate solution was added and made up to a constant volume, then thoroughly mixed. After one hr, the absorption was determined at $725 \mathrm{~nm}$.

The potassium titanium oxalate $(\mathrm{PTO})^{3)}$ method was also used in the estimation of o-diphenols.

All polyphenols were expressed in terms of $\mu \mathrm{mol}$ of gallic acid.

Respiratory measurements. $\quad \mathrm{O}_{2}$-uptake of rice callus cultures were measured manometrically at $30 \mathrm{C}$ in a conventional Warburg apparatus using the method previously described ${ }^{17)}$.

\section{Results}

\section{Regeneration potential of rice callus culture varied the number of transfers}

In order to recognized how the regeneration potential ${ }^{22,25)}$ of rice callus culture differed among the subcultures, organogenesis was examined.

The Murashige-Skoog medium originally containing 2,4-D and yeast extract was replaced with various concentrations $(0.2,0.5,1.0$ and $2.0 \mathrm{mg} / 1$ respectively) of kinetin for the study of morphogenesis. The callus culture was incubated in a growth cabinet (in darkness for $14 \mathrm{hr}$ and in the light for $10 \mathrm{hr}$ ) at $26 \mathrm{C}$.

As shown in Fig. 1, neither organ formation nor chlorophyll were observed in the callus culture transferred for 33 and 54 times. However, the callus culture subcultured one time formed shoots and roots on the medium containing $4 \mathrm{mg} / 1$ kinetin. Roots formation was better on the medium containing 1 or $0.2 \mathrm{mg} / 1$ kinetin. Callus cultures 

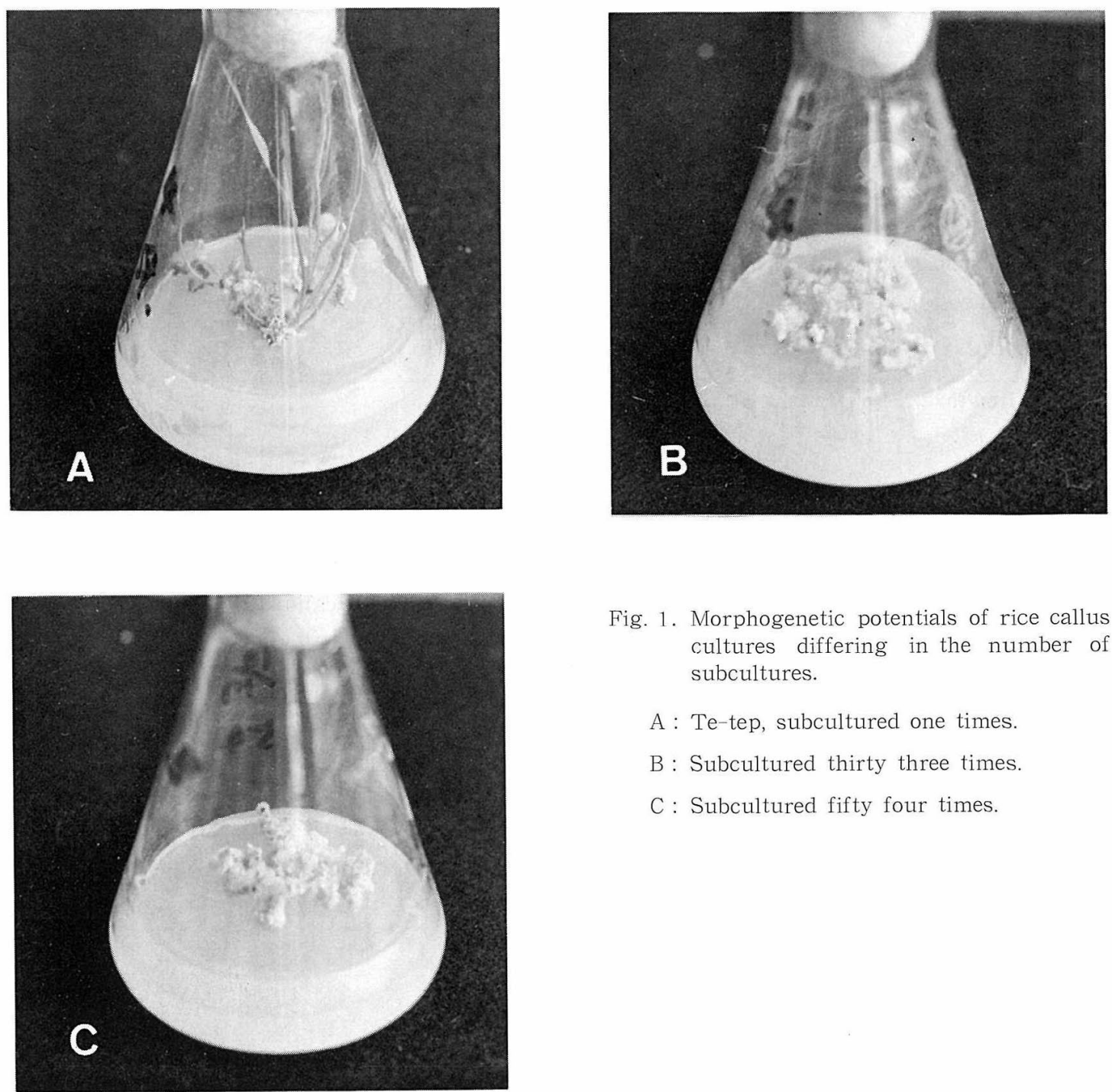

Fig. 1. Morphogenetic potentials of rice callus cultures differing in the number of subcultures.
A : Te-tep, subcultured one times.
B : Subcultured thirty three times.
C : Subcultured fifty four times.

transferred 3, 9, and 18 times, grown on the medium containing 0.3, 0.6, 6 and $9 \mathrm{mg} /$ 1 kinetin, formed chlorophyll. Callus culture transferred 3 times and grown on the medium containing 0.3 and $0.6 \mathrm{mg} / 1$ kinetin formed shoots and roots. The callus culture transferred nine times formed chlorophyll on the medium containing 0.3 or $0.6 \mathrm{mg} /$ 1 kinetin, but no organogenesis was observed. Furthermore, the callus culture transferred 18 times formed roots on the medium containing $0.3 \mathrm{mg} / 1 \mathrm{kinetin}$, but no other morphogenetic changes were observed in the callus culture. This indicates that the regeneration potential of rice callus cultures are reduced with the repeated subculturing. Thus we used the callus cultures transferred one to five times as F callus. 
Table 1. Growth of Pyricularia oryzae $\mathrm{P}_{2}$ and other plant pathogenic fungi on rice callus (Te-tep) differing in the number of subcultures

\begin{tabular}{|c|c|c|c|c|c|c|c|c|}
\hline \multirow[b]{3}{*}{ Incubation time (days) } & \multicolumn{8}{|c|}{ Numbers of subcultures } \\
\hline & \multicolumn{4}{|c|}{30} & \multicolumn{4}{|c|}{$2-5$} \\
\hline & 1 & 2 & 3 & 4 & 1 & 2 & 3 & 4 \\
\hline Pyricularia oryzae $\mathrm{P}_{2}$ & - & + & + & + & - & $\stackrel{+}{i}$ & + & + \\
\hline Fusarium oxysporum & - & $\frac{1}{+}$ & + & + & - & \pm & + & + \\
\hline Alternaria brassicicola & - & + & + & + & - & - & \pm & + \\
\hline Botrytis cinerea & - & + & + & + & - & - & \pm & + \\
\hline
\end{tabular}

+ : Growth; - : No prowth: \pm : Growth barely visible.

The responses of rice callus cultures varying the numbers of subcultures to the infection of $P$. oryzae and other plant pathogenic fungi

$\mathrm{M}$-callus turned brown between 24 to $48 \mathrm{hr}$ after the inoculation of $P$. oryzae and other pathogenic fungi. These fungi readily colonized on the callus cultures. On the other hand, growth of inoculated fungi on F-callus was delayed in comparison with its growth on M-callus, in spite of browning of the callus culture (Table 1).

Fig. 2. Extraction method of spore germination inhibiting substances from infected rice callus cultures.

Lyophilized callus cultures 2-4 g. dr. wt.

Extracted with $60 \mathrm{ml}$ of ethanol over boiling water bath for $60 \mathrm{~min}$.

Ethanol extract

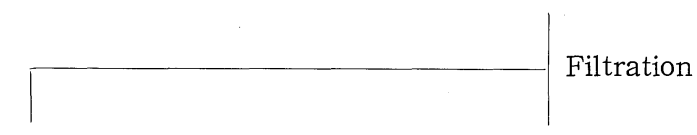

Residue

Filtrate

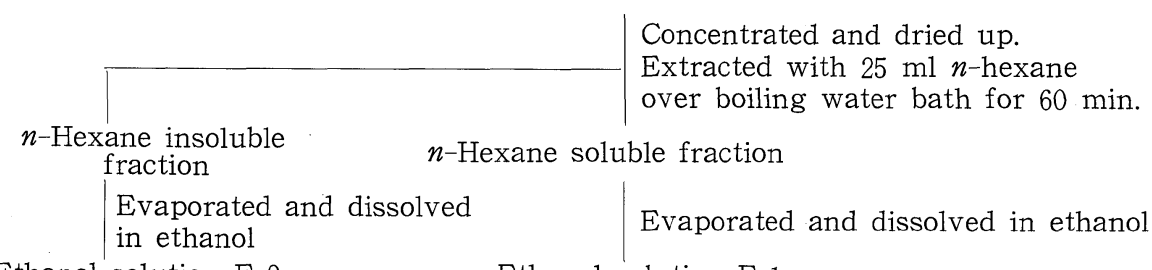

Ethanol solution $\mathrm{F}-2$

Ethanol solution $\mathrm{F}-1$

Growth of $B$. cinerea and $A$. brassicicola on $\mathrm{F}$-callus was greatly inhibited. However, the prevention of growth of $F$. oxysporum was only slight. In the case of $P$. oryzae, the difference of growth on both callus cultures was scarcely detectable. A. oryzae, a saprohytic fungus, grew easily on rice callus cultures irrespective of subculture frequency.

Microscopic observation of thin sections revealed that $A$. brassicicola and $B$. cinerea 
had invaded the cells of $\mathrm{M}$-callus. However, invasion of these fungi into $\mathrm{F}$-callus, transferred 2 times, was not observed, although conidia of these fungi germinated.

Antimicrobial activity in rice callus culture inoculated with plant pathogenic

\section{fungi}

Growth of non-pathogenic fungi to rice plants was delayed on the F-callus compared with its growth on $\mathrm{M}$-callus. This suggested that $\mathrm{F}$-callus might have formed antimicrobial substances ${ }^{14,26)}$ which inhibited growth of the fungi. Therefore, the existence of antimicrobial substances was examined by the germination test of conidia.

Te-tep grown for 20 to 23 days at $30 \mathrm{C}$ was used for this purpose. The callus culture was inoculated with conidia of the test fungi and incubated at $30 \mathrm{C}$ for a fixed time. The callus culture was then taken from the flask and lyophilized.

Antimicrobial substances were extracted from the lyophilized callus culture using the method shown in Fig. 2. The antimicrobial activity of each fraction was tested. A. brassicicola was used as" test microorganisms because of its good germination and characteristic brown color, and form of its conidia. Conidia of $P$. oryzae $\mathrm{P}_{2}$ was also used for some part of this experiment.

The germination test was carried out as follows. A Portion of F-1 and F-2 (Fig. 2) was dissolved in ethanol and $0.1 \mathrm{ml}$ of the solution was poured into a planchet, followed by the addition of $0.9 \mathrm{ml}$ of $1 \%$ agar solution containing $0.1 \mathrm{M}$ phosphate buffer $(\mathrm{pH}$ 5.5). The planchet stood at $28 \mathrm{C}$ in darkness for about $6 \mathrm{hr}$. Then, the spore suspension of the test fungi was spread on an agar planchet and incubated in a Petri dish at $28 \mathrm{C}$. After 6 to $10 \mathrm{hr}$, the percentage of germination was measured by counting the spores which were observed under a microscopic field at $150 \times$ (spore numbers: 50-80). The determination of germination percentage was carried out by counting three planchets and five areas of each planchet. The mean value and standard deviation was calculated for each treatment.

The results are shown in Table 2. Activity was detected in F-1 which was extracted from infected F-callus, but F-2 was not active. F-1 extracted from $\mathrm{M}$-callus did not

Table 2. Spore germination inhibiting activity of A. brassicicola for each fraction extracted from infected and non-infected rice callus differing in the number of subcultures

\begin{tabular}{c|ccc|ccc}
\hline \hline $\begin{array}{l}\text { Number of } \\
\text { subcultures }\end{array}$ & \multicolumn{3}{|c|}{$2-5$} & \multicolumn{2}{c}{24} & \\
\hline Fraction No. & Inoculated & Non-inoculated & Control & Inoculated & Non-inoculated & Control \\
\hline F -1 & $25 \pm 4^{\text {a) }}$ & $85 \pm 4$ & $76 \pm 6$ & $80 \pm 3$ & $83 \pm 3$ & $81 \pm 5$ \\
$F-2$ & $75 \pm 3$ & $84 \pm 5$ & $73 \pm 6$ & - & - & - \\
\hline
\end{tabular}

a) Average of spore germination $(\%) \pm \mathrm{S}$. D. (stadard deviation) Germination inhibiting activity was extracted from Te-tep inoculated with A. brassicicola. Extracts ware dissolved in ethanol $(0.1 \mathrm{~g} / \mathrm{ml})$ and $0.1 \mathrm{ml}$ poured into stainless steel planchets, followed by addition of $0.1 \mathrm{M}$ phosphate buffer ( $\mathrm{pH}$ 5.5) containing $1 \%$ agar.

The conidial suspension of A. brassicicola was placed on the agar and planchets kept in Petri-dish at $28 \mathrm{C}, 10 \mathrm{hr}$. 
Table 3. Production of spore germination inhibitors (Fraction-1) by rice callus (F-callus, Te-tep) inoculated with three species of fungi

\begin{tabular}{l|ccc|ccc|ccc}
\hline Inoculated fungi & Pyricularia oryzae $\mathrm{P}_{2}$ & Alternaria brassicicola & \multicolumn{3}{c}{ Botrytis cinerea } \\
\hline $\begin{array}{l}\text { Conidia used } \\
\text { in germina- } \\
\text { tion test }\end{array}$ & Inocul. & $\begin{array}{l}\text { Non- } \\
\text { inocul. }\end{array}$ & Cont. & Inocul. & $\begin{array}{l}\text { Non- } \\
\text { inocul. }\end{array}$ & Cont. & Inocul. $\begin{array}{c}\text { Non- } \\
\text { inocul. }\end{array}$ & Cont. \\
\hline $\begin{array}{l}\text { Pyricularia } \\
\text { oryzae } \mathrm{P}_{2}\end{array}$ & $88 \pm 2^{\text {a) }}$ & $88 \pm 2$ & $75 \pm 3$ & $22 \pm 7$ & $73 \pm 10$ & $46 \pm 7$ & $26 \pm 7$ & $80 \pm 8$ & $94 \pm 3$ \\
\hline $\begin{array}{l}\text { Alternaria } \\
\text { brassicicola }\end{array}$ & $88 \pm 6$ & $87 \pm 6$ & $80 \pm 6$ & $24 \pm 4$ & $85 \pm 4$ & $73 \pm 7$ & $12 \pm 8$ & $63 \pm 14$ & $73 \pm 10$ \\
\hline
\end{tabular}

a) Average of spore germination $(\%) \pm$ S. D. (standard deviation). Inocul. : Inoculated, Non-Inocul. : Non-inoculated, Cont. : Control.

exhibit any activity. Table 3 shows that the species of fungi inoculated on to callus culture affect the production of this substance. F-1 extracted from F-callus inoculated with $A$. brassicicola and $B$. cinerea exhibited activity to $P$. oryzae and $A$. brassicicola, while that extracted from $F$-callus inoculated with $P$. oryzae exhibited no activity.

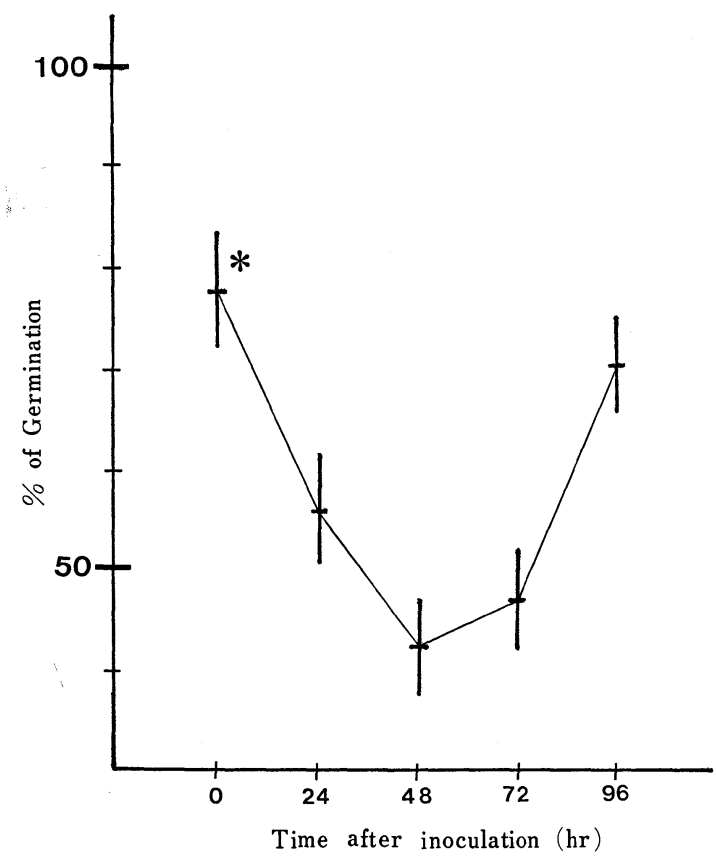

Fig. 3. Time course of the accumulation of spore germination inhibitors.

The activity was tested with subcultured. Te-tep four times and inoculated with $A$. brassicicola. Conidia of $A$. brassicicola were also used for the germination test. Percent germination was determined after $10 \mathrm{hrs}$ of inoculation.

*: Mean value \pm standard deviation
However, in some cases it showed some activity against the conidia of $A$. brassicicola. This may suggest that the production of this substance is lower in the case of callus culture inoculated with the $P$. oryzae $\mathrm{P}_{2}$.

The time course of this activity in F-1 was studied. As shown in Fig. 3, the activity reached its maximum 48 $\mathrm{hr}$ after inoculation and then decreased. The antimicrobial action of this substance extracted $48 \mathrm{hr}$ studied by following the time course of spore germination (Fig. 4). This showed that the action of this substance was weak and only delayed germination. Microscopic observation of the conidia treated with this substance showed that the germination tubers were abnormal since they appeared short and swollen.

\section{Quantitative changes of phenolic compounds in rice callus culture inoculated with fungi}

The increase in the level of phenolic compounds and their antimicrobial ac- 


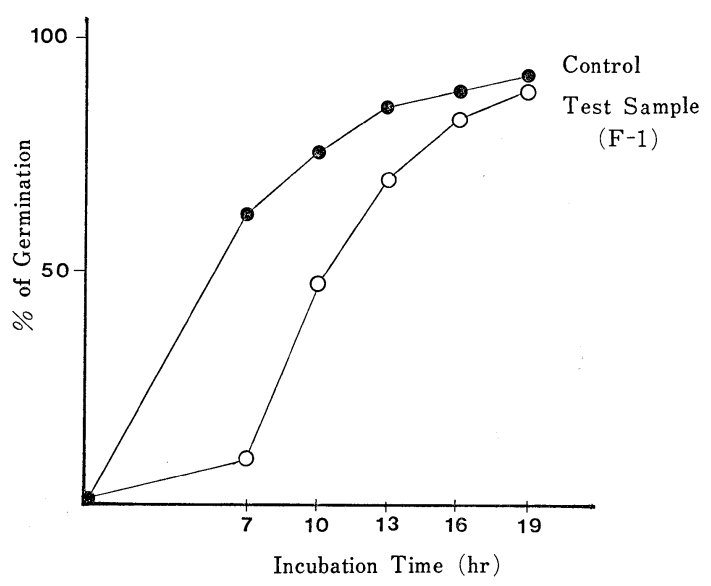

Fig. 4. Time course study of spore germination in the presence of inhibitor.

Test sample was $\mathrm{F}-1$ extracted from rice callus (Te-tep) inoculated with $A$. brassicicola. Concentration of $\mathrm{F}-1$ was $10 \mathrm{mg} / \mathrm{ml}$, and conidia of $A$. brassicicola were used for germination test. tivity in diseased plants is a well knownphenomena. Because rice callus cultures inoculated with conidia turned brown and simultaneously exhibited antimicrobial activity, the quantitative changes of phenolics were examined. Lyophilized rice callus culture was homogenized in a Potter-Elvenjihem homogenizer with $50 \%$ ethanol, followed by centrifugation. The supernatant was used for quantitative estimation of the total phenolic compounds. The Folin-Denis method ${ }^{23)}$ was used. The values were expressed as gallic acid equivalents.

As shown in Table 4, the quantity of phenolic compounds increased slightly in diseased rice callus culture, but there was no correlation between

phenol accumulation and the number of transfers or the fungal species used.

The potassium titanium oxalate method ${ }^{3)}$ (PTO), specific for o-diphenols, was also used to estimate phenolic compounds (Table 5). The increase in the level of phenolic compounds was similar to that of the Folin-Denis method. However, the amounts of phenolic compounds assayed with the PTO method were $1 / 6$ to $1 / 8$ in comparison with the Folin-Denis method. These results indicated that the levels of o-diphenols were

Table 4. Total phenols in rice callus cultures (Te-tep) inoculated with plant pathogenic fungi

\begin{tabular}{|c|c|c|c|c|c|}
\hline \multirow{2}{*}{$\begin{array}{c}\text { Incubation } \\
\text { Times }\end{array}$} & \multirow{2}{*}{$\begin{array}{l}\text { numbers of } \\
\text { subculture }\end{array}$} & \multicolumn{4}{|c|}{ Test fungi } \\
\hline & & $\begin{array}{l}\text { Pyricularia } \\
\text { oryzae } \mathrm{P}_{2}\end{array}$ & $\begin{array}{l}\text { Alternaria } \\
\text { brassicicola }\end{array}$ & $\begin{array}{l}\text { Botrytis } \\
\text { cinerea }\end{array}$ & $\begin{array}{c}\text { Non- } \\
\text { inoculated }\end{array}$ \\
\hline \multirow{5}{*}{$24 \mathrm{hr}$} & 3 & 4400 & 3760 & 3950 & 3580 \\
\hline & 4 & 4520 & 4370 & 4370 & 4220 \\
\hline & 5 & 2860 & 2710 & 1750 & 2320 \\
\hline & 29 & 4220 & 4040 & 一 & 3400 \\
\hline & 69 & 4060 & 4900 & 4450 & 4370 \\
\hline \multirow{6}{*}{$48 \mathrm{hr}$} & 3 & 3670 & 3630 & 3959 & 3210 \\
\hline & 4 & 4450 & 4520 & 5210 & 4450 \\
\hline & 5 & 2860 & 2560 & 1890 & 2480 \\
\hline & & & & i & \\
\hline & 29 & 4220 & 4680 & $-\quad \cdots$ & 4150 \\
\hline & 69 & 4060 & 4670 & 4140 & 3830 \\
\hline
\end{tabular}

Folin-Denis method was used. Polyphenol concentration were expressed in terms of $\mu \mathrm{g}$ of gallic acid per $0.1 \mathrm{~g}$ callus dry weight. 
Table 5. Total phenols in rice callus cultures (Te-tep) inoculated with plant pathogenic fungi

\begin{tabular}{l|c|c|c|c|c}
\hline \hline \multirow{2}{*}{$\begin{array}{c}\text { Incubation } \\
\text { Times }\end{array}$} & $\begin{array}{c}\text { numbers of } \\
\text { subculture }\end{array}$ & $\begin{array}{c}\text { Tyricularia } \\
\text { oryzae } \mathrm{P}_{2}\end{array}$ & $\begin{array}{c}\text { Alternaria } \\
\text { brassicicola }\end{array}$ & $\begin{array}{c}\text { Botrytis } \\
\text { cinerea }\end{array}$ & $\begin{array}{c}\text { Non- } \\
\text { inoculated }\end{array}$ \\
\cline { 3 - 6 } $24 \mathrm{hr}$ & 3 & 646 & 619 & 790 & 575 \\
& 4 & 460 & 458 & 461 & 312 \\
\hline
\end{tabular}

Potassium titanium oxalate (PTO) method was used. Polyphenol concentration were expressed in terms of $\mu \mathrm{g}$ of gallic acid per $0.1 \mathrm{~g}$ callus dry weight.

low and were not increased by the inoculation of fungi.

Changes of phenylalanine ammonia-lyase (PAL) and tyrosine ammonia-lyase $(\boldsymbol{T A L})$ activity in rice callus culture affected with fungi

Phenylpropanoids, flavones and coumarins are biosynthesized through the shikimic acid pathway in which PAL and TAL play important roles. ${ }^{11,15,20,26)}$ Because a slight increase

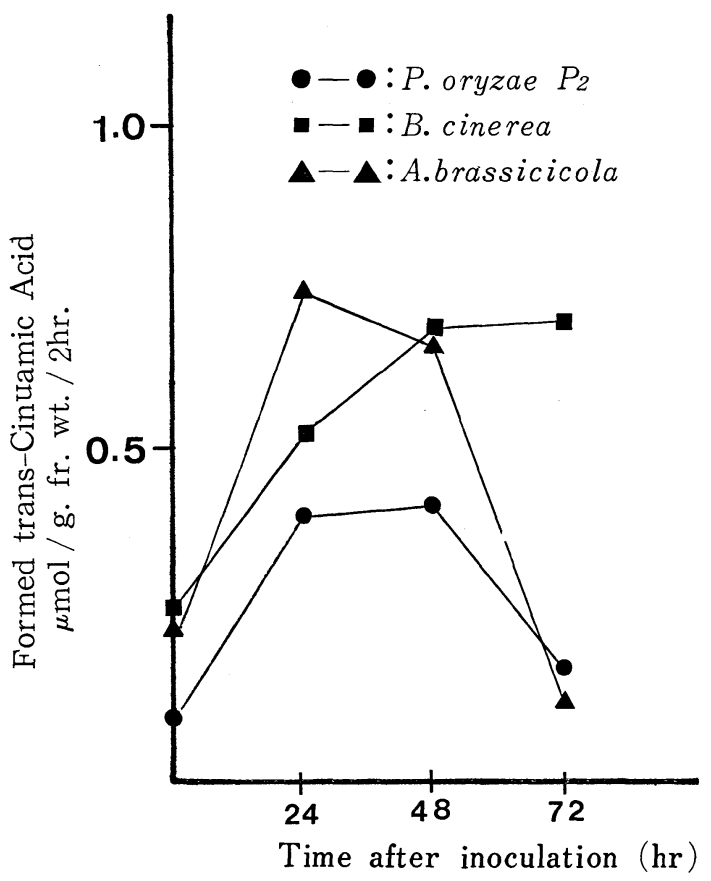

Fig. 5. Time course study of phenylalanine ammonia-lyase activity of rice callus cultures (Te-tep)* inoculated with plant pathogenic fungi.

*: Te-tep subcultured two to four times was used.

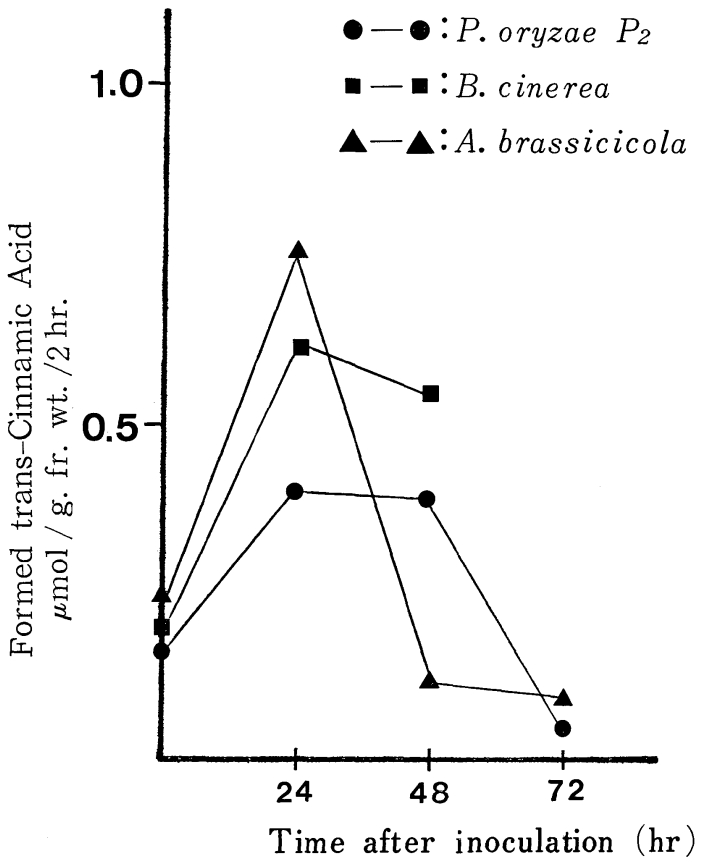

Fig. 6. Time course study of phenylalanine ammonia-lyase activity of rice callus( $\mathrm{Te}^{-}$ tep)* inoculated with plant pathogenic fungi.

*: Te-tep subcultured thirty times was used. 


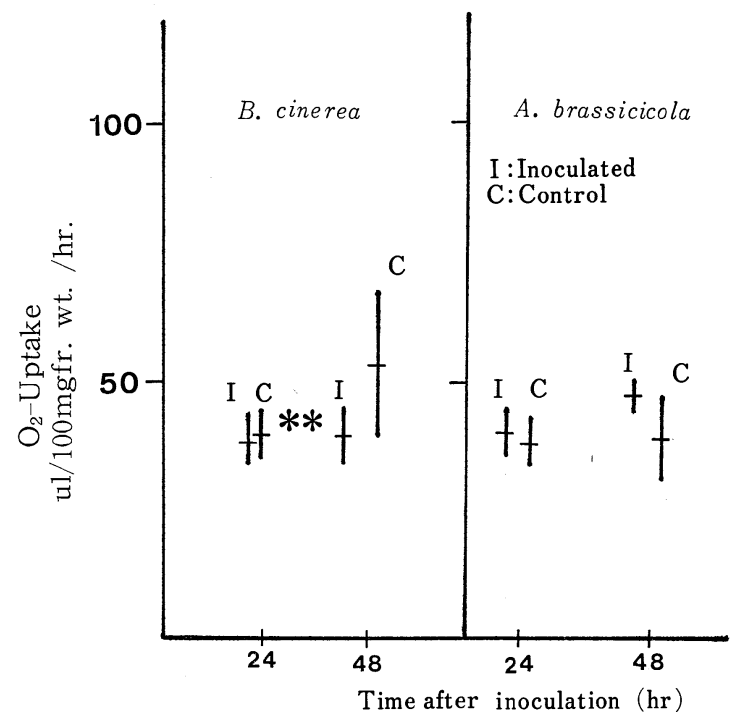

Fig. 7. Time course of $\mathrm{O}_{2}$-uptake of rice callus cultures (Te-tep*) inoculated with plant pathogenic fungi.

*: Te-tep subcultured two to four times was used.

*** Mean value \pm standard deviation

Table 6. Effect of tenuazonic acid to rice callus growth on Murashige-Skoog medium containing increasing concentration of tenuazonic acid

\begin{tabular}{ccc}
\hline \hline $\begin{array}{l}\text { Concentration } \\
\text { of Tenuazonic } \\
\text { acid }(\mu \mathrm{g} / \mathrm{ml})\end{array}$ & Te-Tep & No. 20 \\
\hline 0 & $2.00^{\mathrm{a})}$ & 2.23 \\
12.5 & 1.61 & 2.59 \\
25 & 1.44 & 1.19 \\
50 & 1.12 & 1.32 \\
\hline
\end{tabular}

Both Te-tep and No. 20, subcultured from 2 to 4 times, were used. The callus was incubated for 25 days at $28-30$ C. a) g. fr. wt.

Previously, we reported ${ }^{17)}$ that no increase in the respiration of rice callus cultures inoculated with fungi was observed. An increase in respiration was not observed in infected F-callus (Fig. 7).

\section{Action of tenuazonic acid ${ }^{30)}$, asubstance toxic to rice plants, produced by $P$. oryzae}

We investigated the responses of rice callus cultures to tenuazonic acid since it is produced by $P$. oryzae and $A$. longipes as well.

Rice callus cultures, Te-tep and No. 20 were inoculated on MS medium containing various amount of tenuazonic acid at $28 \mathrm{C}$ in darkness. After 25 days, we observed morphological changes in rice callus culture and then assayed the fresh weight of callus cultures. The data are summarized in Table 6 . in the level of phenolic compounds was observed in rice callus culture infected with fungi, we investigated the changes of PAL and TAL activity in rice callus culture.

The results for PAL are summarized in Figs. 5 and 6 . They show that callus cultures transferred from 2-4 times and 30 times exhibited an increase in the level of enzyme activity $24 \mathrm{hr}$ after inoculation. An approximate 3-4 fold increase in the level of PAL occured with the callus cultures infected by $A$. brassicicola. In the case of the inoculation of $P$. oryzae, the increase of enzyme activity was the lowest among the three tested fungi. But there was no difference between $\mathrm{M}$ and $\mathrm{F}$-callus.

TAL activity was also examined. The enzyme ${ }^{16)}$, in addition to PAL, generally involves polyphenol biosynthesis in monocotyledoneous plants. But $p$-coumaric acid, being a reaction product, was not detected in the UVabsorption spectrum, gas liquid chromatography or gas chromato-mass spectroscopy. So, accordingly, it became obvious that TAL activity did not exist in both healthy and infected rice callus

Changes in respiration rate of rice callus cultures in response to fungal infection 
Tenuazonic acid, at a concentration of $8 \mu \mathrm{g} / \mathrm{ml}$ causes the formation of necrotic spots on rice leaves which resemble those of naturally infected one ${ }^{30)}$. However, no morphological change in the rice callus cultures was observed ever at a concentration of $50 \mu \mathrm{g} /$ m1. As shown in Table 6, only the callus fresh weight decreased with the increase in the concentration of tenuazonic acid.

\section{Discussion}

Tissue cultures appears to have many advantage for the study of host-parasite interaction in certain fungal and viral diseases.

Ingram ${ }^{8)}$, and Robertson and Ingram ${ }^{9)}$ showed that the callus cultures from potato tubers exhibited the same R-gene resistance to Phytophthora infestans as the intact tubers from which they were derived. Similar results have been obtained with tabacco callus cultures to black shank disease (Phytophthora parasitica var. nicotiana) ${ }^{4}$, soybean callus cultures to Phytophthora megasperma var. soja ${ }^{7)}$ and tomato callus cultures to Phytophthora infestans ${ }^{32}$. However, these results were obtained from an observation of the differences in colonization rates on callus cultures derived from resistant and susceptible plants, and the physiological and biological changes of infected callus cultures were scarcely investigated.

In previous papers ${ }^{17,28)}$, we reported the expression of a resistance gene in rice callus culture inoculated $P$. oryzae and other pathogenic fungi. However, it is well known from a number of studies that the various properties of callus cultures are gradually changed by repeated subculturing. The regeneration potential of rice callus cultures was also reduced through repeated subculturing. It was assumed from these evidence that the expression of the resistance gene to fungal infection would also be reduced successive subcultures. But, even with a limited number of subcultures, $P$. oryzae $\mathrm{P}_{2}$ readily invaded the rice callus cultures and resistance reactions, such as hypersensitive reaction, were not observed.

Ishii ${ }^{10)}$ investigated the stage at which the rice blast resistance gene of rice plants are first manifested using rice callus cultures. His experiments were carried out using rice varieties having different blast resistance genes and different blast fungi which had pathogenic genes complementary to the resistance genes. The hyphal invasion and extension of the fungus in callus cultures was clearly recognized, but no difference was found among the rice varieties. From these data, they concluded that resistance genes did not manifested themselves in rice callus cultures.

However, with the exception of the saprophytic fungus, A. oryzae, F-callus exhibited a resistance reaction to other plant pathogenic fungi having no pathogenicity to rice plants. It has become clear that the resistance reaction was based on antimicrobial substances which were produced by infected rice callus cultures.

A wide varieties of plants species infected by plants pathogenic fungi exhibit a general reaction which is expressed as an increase of respiration ${ }^{27,31)}$. Furthermore, they show that the induced respiration coupling with energy forming reaction is important in exhibiting the resistant reaction. But the respiration of rice callus cultures was not increased by infection with fungi. This result is a very important difference between 
rice leaf and callus cultures.

It is well known that phenolic compounds accumulate around infected cells ${ }^{19)}$ and that some of these compounds are correlated with a defense reaction ${ }^{2}$. In our experiments, phenolic compounds increased slightly and PAL activity increased 3 to 4 times in rice callus cultures inoculated with fungi. However, there was no difference between $\mathrm{M}$-and $\mathrm{F}$-callus.

Small amounts of $p$-coumaric and $p$-hydroxybenzoic acid were detected in the rice callus cultures extract, instead of large amounts of the $p$-coumaric and ferulic acid contained in rice leaves ${ }^{13)}$.

Responses of rice callus cultures to tenuazonic acid, one of toxins produced by rice blast fungus, differed from that of the rice leaf and only an inhibition of growth was observed with increasing the amount of tenuazonic acid.

As stated above, responses of rice callus cultures to fungal infection differed from that of mature rice plants.

Our results also indicate that expression of $\mathrm{R}$-gene action in rice plants is not exhibited in rice callus cultures.

The authers would like to thank Dr. K. Umetsu, Otsuka Pharmaceutical Co. Ltd., for providing the valuable sample of tenuazonic acid.

The authors also wish to thank Assistant Professor, D. Hildebrand, University of Kentucky, for critical reading of the manuscript.

\section{Literature cited}

1. Berlin, J. and Barz, W. (1971). Planta $98: 300-314$.

2. Condon, P. and Kuć, J. (1960). Phytopathology $50: 267-270$.

3. Forrest, G. I. and Bendall, D. S. (1969). Biochem. J. 113:741-755.

4. Helgeson, J. P., Kemp, J. D., Haberlach, G. T. and Maxwell, D. P. (1972). Phytopathology 62 : 1439 -1443 .

5. Helgeson, J. P, Haberlach, G. T. and Upper, C.D. (1976). Phytopathology 66:91-96.

6. Heim, J.M. and Gries, G. A. (1953). Phytopathology $43: 343-344$.

7. Holliday, M. J. and Klarman, W. L. (1976). Phytopahtology 69 : 266-269.

8. Ingram, D. S. (1967). J. Gen. Microbiol. 49: 99-108.

9. Ingram, D. S. (1969). J. Gen. Microbiol. 58: 391-401.

10. Ishii, K. (1978). Ph. D. Thesis, Nihon University.

11. Kosuge T. (1969). Ann. Rev. Phytopath. $7: 195-222$.

12. Koukol, J. and Conn, E. E. (1961). J. Biol. Chem. $236: 2692-2698$.

13. Kuwazuka, S. (1962). Ph. D. Thesis, Kyushu University.

14. Maheshwari, R., Hildebrant, A. C. and Allen, P. J. (1967). Bot. Gaz. 128 : 153-159.

15. Minamikawa, T., and Uritani, I. (1965). J. Biochem. $57: 678-688$.

16. Neish, A. C. (1961). Phytochemistry $1: 1-24$.

17. Ogasawara, N., Uchiyama, T., Ohashi, T. and Tanaka, H. (1977). Ann. Phytopath. Soc. Japan $43: 246-254$.

18. Reinert, J. and Bajaji, Y.P.S. (1977). Applied and Fundamental Aspects of Plant Cell, Tissue and Organ Culture. Springer-Verlag. pp. 3-207, 581-633, 649-703.

19. Sakai, R. and Tomiyamam, K. (1964). Ann. Phytopath. Soc. Japan $29: 33-38,120-127$.

20. Stafford, H. A. (1974). Ann. Rev. Plant Physiol. 25 : 459-486.

21. Street, H.E (1973). Plant Tissue and Cell Culture. Blackwell Scientific Publication. pp. 338$354,392-420$.

22. Syono, K. (1965). Plant \& Cell Physiol. $6: 403-419$.

23. Swain, T. and Hillis, W.E. (1959). J. Sci. Food Agric. 10:63-65. 
24. Takeuchi, M., Ishihara, T. and Furuya, C. (1972). Shokubutsu Soshiki Baiyo. Asakura Shoten (Tokyo). pp. 265-452.

25. Tamura, S (1968). Proc. Japan Academy $44: 544-548$

26. Tomiyama, K. (1970). Shokubutsu No Kagakuchosetsu $5: 105-115$.

27. Toyoda, S. and Suzuki, N. (1960). Ann. Phytopath. Soc. Japan $25: 172-177$.

28. Uchiyama T. and Ogasawara, N. (1977). Agric. Biol. Chem. 41:1401-1405

29. Uchiyama T., Sato, J. and Ogasawara, N. (1983). Agric. Biol. Chem. 47 : 1-10.

30. Umetsu, N., Kaji, J. and Tamari, K. (1972). Agric. Biol. Chem. 36: 859-866.

31. Uritani, I. and Asahi, T. (1980). The Biochemistry of Plants. Vol. 2, ed. by Davis, D. D. pp. 463483.

32. Warren, R.S. and Routly, D. G. (1970). J. Amer. Soc. Hort. Sci. 95 : 266-269.

33. Yamada, Y. (1971). Shokubtsu No Kagakuchosetsu $6: 138-149$.

34. Yokoyama, T. and Takeuchi, M. (1981). J. Japan Soc. Hort. Sci. 49 : 557-562.

和 文 摘 要

\author{
継代回数を異にするイネカルスの植物病原 \\ 糸状菌接種に対する反応 \\ 内山武夫・加藤博美・伊藤正子 ・ 小笠原長宏
}

カルスの継代による性質の変化は良く知られた現象である。筆者等はイネカルスで継代による再分化能の低 下を確認すると同時に，いもち病菌を初め数種の植物病原系状菌を，継代回数を異にするイネカルスに接種し て，それらが示す反応について調べた。

イネカルスへ接種されたいもち病菌の侵入と生育が，誘導初期カルス（月 1 回の割合で継代 5 回までのも の：F-カルスと略す）および長期継代カルス（2 年以上継代したもの：M-カルスと略す）共に認められた。 しかし，イネには病原性を示さない植物病原系状菌接種に対し F-カルスは抵抗反応を示した。

これは F-カルスが菌の接種により胞子発芽阻害物質を生成する為と推論された。しかし，その作用は静菌 的で弱かった。

フェノール性物質の量的変化を調べたととろフェニールアラニンアンモニアリアーゼ活性の増大にあかかわ らず，その顕著な増加は見られなかった。また，菌の接種による酸素吸収量の変化む認められなかった。

いもち病菌の生産する毒素であるテヌアゾン酸に対する反応は，その濃度の増加と共に力ルスは生育阻害を

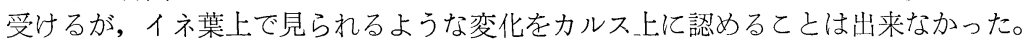

これらの結果から, F-カルスにおいてあ異物拒否反応は弱く, 菌の種類にかかわらずそれが有する侵入力に より容易に侵害されることが明らかとなった。 